\title{
ROLE OF TUMOR-DERIVED FIBROBLASTS IN THE GROWTH OF PRIMARY CULTURES OF HUMAN BREAST-CANCER CELLS: EFFECTS OF EPIDERMAL GROWTH FACTOR AND THE SOMATOSTATIN ANALOGUE OCTREOTIDE
}

\author{
Leo J. Hofland ${ }^{1,4}$, Bart van Der BurG ${ }^{3}$, Casper H.J. van EIJCK ${ }^{2}$, Diana M. SPRIJ ${ }^{1}$, Peter M. van Koetsveld ${ }^{1}$ \\ and Steven W.J. LAMBERTS ${ }^{1}$ \\ Departments of ${ }^{1}$ Internal Medicine III and ${ }^{2}$ Surgery, Erasmus University Rotterdam, Rotterdam; and ${ }^{3}$ Hubrecht Laboratory, \\ Utrecht, The Netherlands.
}

\begin{abstract}
In the present study we have investigated the role of human breast-cancer-derived fibroblasts in the proliferation of primary cultures of epithelial cells derived from the same tumor. For this purpose, a co-culture system, using Transwell tissue-culture inserts with microporous membranes was employed. Fibroblasts and epithelial cells were enriched according to differences in their density on Percoll density gradients. The coculture system was first established using MCF-7 breast cancer cells and a human fibroblast line (HF cells). Insulin, I7/-estradiol, EGF and HF cells all significantly stimulated the growth of MCF-7 breast cancer cells. The stimulatory effects of insulin, E2 and EGF were additive to the stimulatory effect of HF cells. These data suggest that (unique) factor(s), other than the above-mentioned growth-promoting compounds, are responsible for the growth-promoting effects of fibroblasts. In half of the human breast cancers investigated, tumor-derived fibroblasts stimulated tumor-derived epithelial cell proliferation. EGF significantly stimulated epithelial cell proliferation in 4 out of 6 cultures. The stimulatory effects of fibroblasts and EGF were additive or synergistic, and were observed in the additional presence of FCS, again suggesting production of unique factor(s) by the fibroblasts. In one culture the fibroblasts significantly inhibited epithelial tumor-cell proliferation. Conversely, the epithelial cells significantly stimulated proliferation of fibroblasts in 3 out of 3 cultures. The somatostatin analogue octreotide significantly inhibited epithelial cell proliferation by $46 \%$ in one tumor-cell culture in the absence, but not in the presence, of fibroblasts. In one culture, octreotide significantly inhibited the proliferation of fibroblasts co-cultured with epithelial cells.

o 1995 Wiley-Liss, Inc
\end{abstract}

Culturing primary human breast-cancer cells has proved to be difficult. The most successful method appears to be treatment of the tissue with collagenase, subsequent $1 \mathrm{~g}$ sedimentation of epithelial clumps and culture of the cells in media with specific substitutes (Band and Sager, 1989; Smith, 1991). One of the reasons underlying the difficulties of culturing such cells may be the dependance of individual cancer cells upon an intact autocrine and paracrine growth-regulatory apparatus which is proposed to exist in vivo (Lippman et al., 1986; Osborne and Arteaga, 1990). Recent laboratory studies also point to an important role of stromal cells in the development and growth of breast cancer. Conditioned media from human breast-cancer-derived fibroblasts have been shown to enhance the growth of several human breast-cancer cell lines via the secretion of (unknown) growth factors (Enami et al., 1983; Adams et al., 1988; van Roozendaal et al., 1992). This stimulatory effect of stromal cells on the growth of malignant breast epithelial cells has also been demonstrated in vivo (Horgan et al., 1987, 1988).

The importance of stromal-epithelial interactions in the growth of epithelial tumor cells led us to investigate the growth of primary cultures of human breast-cancer cells in the absence or presence of the corresponding tumor-derived fibroblasts. For this, we first separated the epithelial cells from the fibroblasts on discontinuous Percoll density gradients. This method of enrichment of breast cancer-cell populations has already been applied successfully (Sykes et al., 1970). Thereafter, we co-cultured both cell populations using Transwell tissue-culture inserts with microporous membranes. In addition, we also studied the effects of EGF and the somatostatin analogue octreotide in this co-culture system. A nonhomogeneous distribution of receptors for somatostatin has been demonstrated by autoradiography (Reubi et al., 1990) in $46 \%$ of large tumor samples of human breast-cancer tissues, while in the same study $25 \%$ of the somatostatin-receptorpositive breast tumors were shown to contain EGF-receptors. These 2 receptor types were not topographically overlapping in the majority of the cases, however. The growth factor and the neuropeptide may be involved in positive and negative growth regulation of human breast cancer cells, respectively. More knowledge about the interrelationship between the direct and indirect effects of octreotide and EGF on the growth of human breast-cancer cells is of clinical importance in the light of recent clinical trials in which patients with advanced breast cancer have been treated with octreotide (Vennin et al., 1989). The co-culture system using Transwell tissue-culture inserts was first established using MCF-7 human breast cancer cells and human fibroblasts (HF cells).

\section{MATERIAL AND METHODS}

Cell dispersion and separation of cells according to differences in density

Fresh tissue from 6 malignant breast tumors was obtained within $30 \mathrm{~min}$ of surgical removal. Histological diagnosis of tumor tissue was confirmed by routine histo-pathological examination. Table I shows the tumor characteristics. The tissue was minced into pieces of approximately $1 \mathrm{~mm}^{3}$, washed twice with isolation medium (see below), centrifuged at $100 \mathrm{~g}$ for $5 \mathrm{~min}$, and incubated overnight in culture medium containing $2 \mathrm{~g} / \mathrm{l}$ collagenase. Thereafter, the remaining cell pellet was washed twice with isolation medium and incubated for another $1 \mathrm{hr}$ at $37^{\circ} \mathrm{C}$ with a mixture of collagenase and dispase $(1 \mathrm{~g} / 1$ and $2.4 \times 10^{3} \mathrm{U} / \mathrm{l}$, respectively) to obtain a single-cell suspension. After this incubation period the cells were washed twice with isolation medium. The remaining cell suspension then consisted of single cells. An aliquot of this suspension was separated and the cells were counted and plated in multi-well plates (see below); these represent the original cell suspension. The remaining cells were layered on a discontinuous Percoll density gradient (1.04-1.05-1.06-1.07-1.08-1.10 g/ml) and centrifuged to isodensity for $20 \mathrm{~min}$ at $800 \mathrm{~g}$. The cells

${ }^{4}$ To whom correspondence and reprint requests should be sent, at the Department of Internal Medicine III, University Hospital Dijkzigt, Dr. Molewaterplein 40, 3015 GD Rotterdam, The Netherlands. Fax: 31104635430 .

Received: May 28, 1994 and in revised form August 2, 1994 
TABLE I - CHARACTERISTICS OF TUMORS STUDIED

\begin{tabular}{ccccc}
\hline $\begin{array}{c}\text { Tumor } \\
\text { number }\end{array}$ & $\begin{array}{c}\text { Age of } \\
\text { patient }(\mathrm{yr})\end{array}$ & $\begin{array}{c}\text { SBR } \\
\text { (grade) }^{1}\end{array}$ & $\begin{array}{c}\text { Pathol. } \\
\text { stage }^{2}\end{array}$ & ER status $^{3}$ \\
\hline 1 & 36 & III & $\mathrm{T}_{1} \mathrm{~N}_{1 \mathrm{~h}}$ & - \\
2 & 60 & III & $\mathrm{T}_{2} \mathrm{~N}_{0}$ & + \\
3 & 44 & II & $\mathrm{T}_{1} \mathrm{~N}_{0}$ & + \\
4 & 72 & II & $\mathrm{T}_{1} \mathrm{~N}_{0}$ & + \\
5 & 68 & $\mathrm{I}$ & $\mathrm{T}_{2} \mathrm{~N}_{1 \mathrm{a}}$ & + \\
6 & 51 & $\mathrm{I}$ & $\mathrm{T}_{2} \mathrm{~N}_{1 \mathbf{a}}$ & + \\
\hline
\end{tabular}

'Scarff, Bloom and Richardson grade.- ${ }^{2} T_{1}$, tumor size $<2 \mathrm{~cm}$; $\mathrm{T}_{2}$, tumor size between 2 and $5 \mathrm{~cm} ; \mathrm{N}_{0}$, no positive axillary lymph-nodes; $\mathrm{N}_{1 \mathrm{a}}$, positive axillary lymph-nodes; $\mathrm{N}_{\mathrm{bb}}$, positive axillary top lymph-node. $-{ }^{3}$ Estrogen receptor assessed by immunohistochemistry; -, negative; + , positive.

present in the different fractions (interphases) were collected, washed twice with isolation medium, counted and cultured as described below. Percoll was obtained from Pharmacia (Uppsala, Sweden).

\section{Cell culture}

The human epithelial tumor cells with equilibrium densities of $>1.07 \mathrm{~g} / \mathrm{ml}$ (Sykes et al., 1970), were resuspended in culture medium, counted and seeded in multi-well plates at a concentration of 25,000 cells per well. Fibroblasts with an equilibrium density of $<1.05 \mathrm{~g} / \mathrm{ml}$ (Sykes et al., 1970) were resuspended in culture medium, counted and seeded $(25,000$ cells per Transwell microporous membrane, $0.4 \mu \mathrm{m}$; Costar, Badhoevedorp, The Netherlands). The Transwells were transferred into wells containing $1 \mathrm{ml}$ of culture medium with or without epithelial cells. Thereafter, the epithelial cells (with or without fibroblasts) were incubated with or without test substances for 5-7 days. During the last $24 \mathrm{hr}, 3.7 \times 10^{4} \mathrm{~Bq}$ of [methyl- ${ }^{3} \mathrm{H}$ ]thymidine were added to the wells. The medium was removed, then the cells were washed twice with ice-cold $0.15 \mathrm{~mol} / 1 \mathrm{NaCl}$, suspended in $1 \mathrm{~mol} / \mathrm{l} \mathrm{NaOH}$ and transferred to vials for scintillation counting of the incorporated radioactivity.

The isolation medium was Hanks' balanced salt solution (HBSS) supplemented with $10 \mathrm{~g} / 1$ human serum albumin, penicillin $\left(10^{5} \mathrm{U} / \mathrm{l}\right)$ and sodium bicarbonate $(0.4 \mathrm{~g} / \mathrm{l})$. Culture medium consisted of DMEM/F-12 (1:1) supplemented with non-essential amino acids, FCS (10\%), human transferrin (10 $\mu \mathrm{g} / \mathrm{l}$; Sigma, St Louis, MO), ascorbic acid $(50 \mu \mathrm{M})$ and sodium selenite $(6 \mu \mathrm{g} / \mathrm{l})$. Media and supplements were obtained from Gibco-BRL (Paisley, UK). Human transferrin and ascorbic acid were obtained from Sigma, and sodium selenite from Merck (Darmstadt, Germany).

MCF-7 human breast cancer cells were kindly provided by Dr. C. Quirin-Stricker (Faculté de Médecine, Strasbourg, France). Fibroblasts isolated from human foreskins (HF cells) were kindly provided by Dr. M. Ponec (Leiden, The Netherlands). MCF-7 and HF cells were cultured in culture medium and passaged twice a week using trypsin $(0.05 \%)$ and EDTA $(0.02 \%)$. In the experimental incubations, the MCF-7 cells $(25,000$ cells seeded per well) were cultured in multi-well plates in $1 \mathrm{ml}$ culture medium with or without HF cells $\left(2 \times 10^{5}\right.$ cells per Transwell). After 1 day of culture, the medium was replaced by serum-free culture medium. After another 1 day of incubation, this medium was replaced by medium containing $10 \%$ growth-factor-inactivated FCS and the cells were incubated for 2 days with or without test substances. Under these conditions optimal stimulation of MCF-7 cell proliferation by mitogens such as insulin or insulin-like growth factors is observed (van der Burg et al., 1988). At the end of the incubation the DNA content of the cells was measured using the bisbenzimide fluorescent dye (Behring, La Jolla, CA) as described previously (Hofland et al., 1990).
Insulin (bovine) was purchased from Sigma and epidermal growth factor from Bissendorf (Hanover, Germany).

\section{Immunocytochemical detection of keratin and $B U d R$}

For keratin and BUdR staining, the epithelial cells were cultured on glass coverslips. For keratin staining, the cells were fixed for 10 min with methanol at the end of the incubation period. Staining for keratin was done with a PAP Kit System (code K518; DAKO, Glostrup, Denmark). For BUdR staining, the cells were incubated for $60 \mathrm{~min}$ with 5-bromo-2'deoxyuridine, washed twice with PBS, and fixed for $20 \mathrm{~min}$ at $-20^{\circ} \mathrm{C}$ in $70 \%$ ethanol in glycin buffer $(50 \mathrm{mmol} / \mathrm{l}, \mathrm{pH} 2.0)$. Staining for BUdR was done with a BUdR labelling and detection Kit II from Boehringer (cat. 1299 964; Boehringer Mannheim, Almere, The Netherlands). The cells were doublestained for keratin with the PAP Kit System, as described above.

\section{Statistical analysis of data}

All values are expressed as mean $\pm \mathrm{SE}, \mathrm{n}=3$ wells per treatment group. All data were analyzed using analysis of variance (ANOVA) to determine overall differences between treatment groups. When significant overall effects were found by ANOVA, a comparison between treatment groups was made using the Newman-Keuls test (Snedecor and Cochran, 1980 ). A value of $p<0.05$ was considered to be statistically significant.

\section{RESULTS}

\section{Fibroblast-epithelial-cell interactions in cell lines}

We first established the co-culture system using Transwell tissue-culture inserts in MCF-7 human breast cancer cells co-cultured with human fibroblasts (HF cells). In initial experiments we determined the number of HF cells that were required to significantly stimulate MCF-7 cell proliferation. Figure 1 shows that a low number of HF cells $(10,000-20,000$ HF cells seeded per Transwell) only slightly stimulated MCFcell proliferation, while a higher number $(200,000$ cells $)$ stimulated MCF-7 cell proliferation by $76 \%$. In the further co-culture studies we therefore used this higher number of $\mathrm{HF}$ cells. In Figure 2 the effects of $17 \beta$-estradiol (E2) and insulin on MCF-7 cell growth with or without co-culture with HF cells

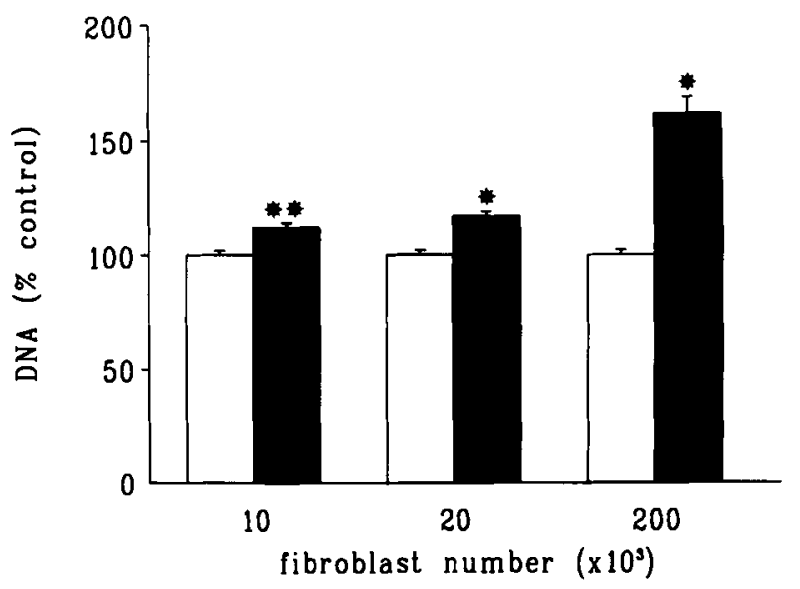

FigURE 1 - Effect of human fibroblasts (HF cells) on the growth of MCF-7 breast-cancer cells. HF and MCF-7 cells were cocultured for 4 days using Transwell tissue-culture inserts with microporous membranes as described in the text. $\square$, MCF-7 cells without HF cells; 2 , MCF-7 cells with HF cells; ${ }^{*} p<0.01$ and ${ }^{* *} p<0.05$ vs. MCF- 7 cells without HF cells. 


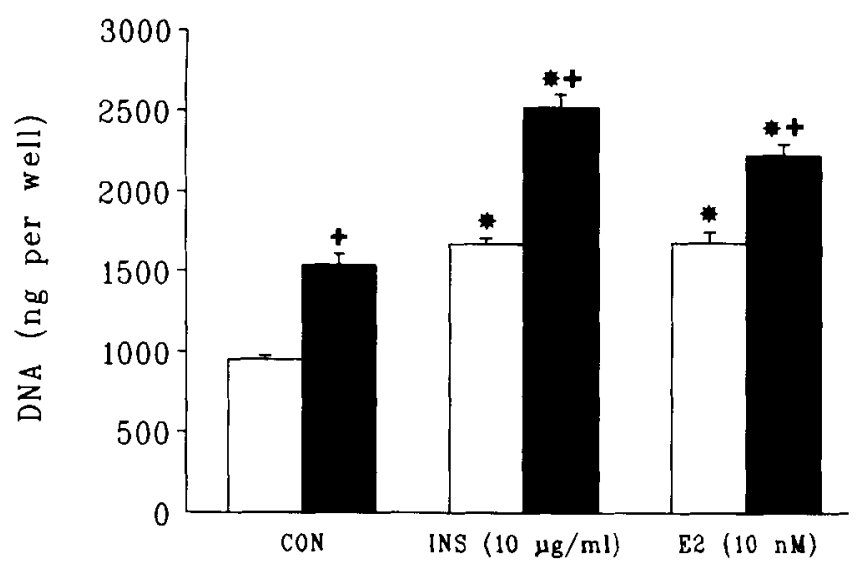

Figure 2 - Effect of insulin (INS) and 17ß-estradiol (E2) on MCF-7 cell growth, with ( $\square$ ) or without $(\square)$ co-culture with human fibroblasts (HF cells). MCF-7 and HF cells were cocultured for 4 days as described in the text. Insulin $(10 \mu \mathrm{g} / \mathrm{ml})$ and E2 $(10 \mathrm{nM})$ were added on day 3 of culture. ${ }^{*} p<0.01 \mathrm{vs}$. control; ${ }^{+} p<0.01$ vs. cells without HF cells.

is shown. The HF cells significantly stimulated proliferation of MCF-7 cells ( $+61 \% ; p<0.01$ vs. cells without HF cells). E2 $(10 \mathrm{nM})$ and insulin $(10 \mu \mathrm{g} / \mathrm{ml})$ alone significantly stimulated MCF- 7 cell proliferation by 76 and $75 \%$, respectively $(p<0.01$ vs. control cells). The effects of E2 and insulin were additive and not synergistic to the stimulatory effect of the HF cells on MCF-7 cell proliferation. EGF $(10 \mathrm{ng} / \mathrm{ml})$ had, under these conditions, only a marginally stimulating effect $(+25 \%, p<$ 0.01 vs. control cells). Again, the effect of EGF was additive to the effect of HF cells on MCF-7 cell growth (data not shown).

\section{Staining for keratin and incorporation of $B U d R$ in primary cultures of human breast-cancer cells}

In initial experiments, we cultured cells from all fractions of the Percoll density gradients. On the basis of hematoxylinstained preparations of these fractions, we found that cells with densities of less than $1.05 \mathrm{~g} / \mathrm{ml}$ had a fibroblast-like appearance, while those with a density of more than $1.07 \mathrm{~g} / \mathrm{ml}$ were clearly epithelial-like. The intermediate density fractions showed a mixture of both cell types. In the subsequent studies we therefore used cells with densities of $<1.05 \mathrm{~g} / \mathrm{ml}$ (fibroblast enriched) and $>1.07 \mathrm{~g} / \mathrm{ml}$ (epithelial-cell enriched) only. The original, unseparated, cultured-cell suspension consisted of both cell types, with a preponderance of fibroblasts. We also observed in most cultures that the Percoll-enriched fraction of epithelial cells grew best in the presence of fibroblasts and EGF $(10 \mathrm{ng} / \mathrm{ml})$. Figure $3 a$ shows an example of the staining for keratin of an epithelial cell population co-cultured with fibroblasts and EGF $(10 \mathrm{ng} / \mathrm{ml})$. Virtually no fibroblasts (keratin-negative) are present. Figure $3 b$ shows absence of staining when non-immune rabbit serum is used instead of rabbit antiserum to human keratin proteins.

An example of double staining for keratin and BUdR in proliferating cells from the same tumor is shown in Figure $3 c$ and $d$. Figure $3 c$ shows that in the original, unseparated cell suspension both proliferating fibroblasts (blue nucleus, keratinnegative) and epithelial cells (blue nucleus, keratin-positive) are present. In contrast, Figure $3 d$ shows that, in the enriched epithelial fraction, mainly proliferating epithelial cells are present. Therefore, measurement of ${ }^{3} \mathrm{H}$-thymidine incorporation in the enriched epithelial-cell fraction will indeed represent proliferation of epithelial cells, and we therefore performed further studies of the effects of fibroblasts on the proliferation of enriched epithelial breast-cancer cells. We also used this co-culture system to study the effects of EGF (10 $\mathrm{ng} / \mathrm{ml}$ ) and the somatostatin analogue octreotide (1 $\mathrm{nM})$.

Effect of tumor-derived fibroblasts on ${ }^{3} \mathrm{H}$-thymidine incorporation in tumor-derived epithelial cells

Figure 4 shows the effect of Percoll-enriched fibroblasts (F) on ${ }^{3} \mathrm{H}$-thymidine incorporation of Percoll-enriched tumorderived epithelial cells of 6 breast cancers. The fibroblast fraction significantly stimulated ${ }^{3} \mathrm{H}$-thymidine incorporation in 3 out of 6 cultures (numbers 1,2 and 5), and inhibited ${ }^{3} \mathrm{H}$-thymidine incorporation in one (number 3$)$. EGF (10 $\mathrm{ng} / \mathrm{ml}$ ) alone significantly stimulated ${ }^{3} \mathrm{H}$-thymidine incorporation in 4 out of 6 cultures $(3,4,5,6)$. The effects of fibroblasts and EGF were significantly synergistic in 2 cultures (1 and 4 ), and additive in another (5). In contrast, in the culture of tumor 3 the fibroblast fraction significantly inhibited EGF-stimulated ${ }^{3} \mathrm{H}$-thymidine incorporation.

In 2 cultures from histologically proven non-malignant tissues ( 1 blunt duct adenosis and 1 chronic granulomatous inflammation) we found that the fibroblast fraction inhibited epithelial cell growth, while in one the fibroblast fraction completely blocked EGF-induced stimulation of epithelial cell proliferation (data not shown).

The somatostatin analogue octreotide $(1 \mathrm{nM})$ had no statistically significant effect on epithelial cell proliferation either in the absence or in the presence of fibroblasts in tumors $1,2,4,5$ and 6 , whereas in tumor 3 octreotide significantly inhibited epithelial-cell proliferation by $46 \%$ ( $p<0.01$ vs. control) only in the absence of fibroblasts (data not shown).

In 3 cultures (tumors 2,5 , and 6 ) we also studied ${ }^{3} \mathrm{H}$-thymidine incorporation in fibroblasts cultured in the absence and in the presence of epithelial cells. In addition to the stimulatory effect of tumor-derived fibroblasts on epithelial cell proliferation, we found that the Percoll-enriched epithelial cells also significantly stimulated fibroblast proliferation. This is shown in Figure 5. In the presence of epithelial cells, EGF $(10 \mathrm{ng} / \mathrm{ml})$ significantly stimulated fibroblast proliferation in all cultures (Table II). In fibroblasts, co-cultured with epithelial cells, octreotide significantly inhibited ${ }^{3} \mathrm{H}$-thymidine incorporation in 1 out of 6 cultures (number 5). Insufficient stromal cells were obtained after Percoll-gradient separation to allow us to study the effects of EGF and octreotide on the growth of fibroblasts that were not co-cultured with tumor-derived epithelial cells.

\section{DISCUSSION}

Previous studies have demonstrated that human breastcancer-derived stromal cells secrete factors capable of stimulating the proliferation of breast-cancer cell lines (Enami et al., 1983; Adams et al., 1988; van Roozendaal et al., 1992). While mammary tumor epithelial cell growth is regulated by steroid hormones and polypeptide growth factors (Lippman et al., 1986; Osborne and Arteaga, 1990; Rosen et al., 1991), the nature of the stromal factors responsible for stimulation of epithelial cell growth is still unclear. The present study employed a co-culture system using Transwell microporous membrane inserts to investigate the role of human breastcancer-derived fibroblasts in the growth regulation of epithelial cells derived from the same corresponding tumors. This co-culture system was first established with MCF-7 breastcancer cells co-cultured with a human fibroblast line (HF cells). In agreement with other studies (Adams et al., 1988; van der Burg et al., 1990; van Roozendaal et al., 1992) we found that fibroblasts are capable of stimulating the proliferation of MCF-7 breast-cancer cells.

Most studies on stromal-epithelial interactions in human breast cancer have been performed using conditioned media 

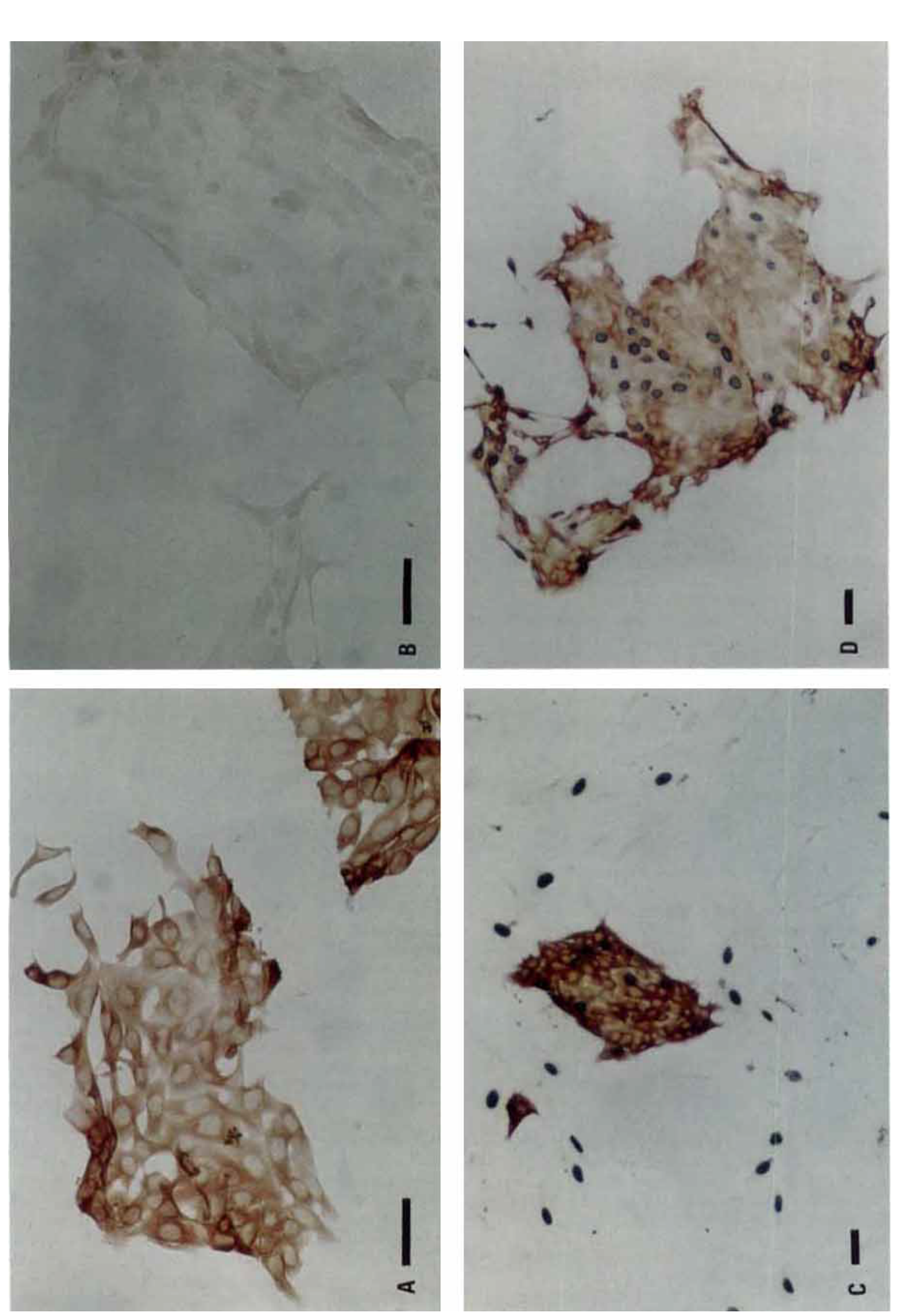

宊

的要

氕产

的包

줌ำ

熍

탱ㅎㅇ물

产䱏

응

要它

讨

远

$\stackrel{0}{\bar{\nabla}} \cong$

造

采

产气氞

E棺

3

몸후워

焉它需

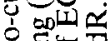

8.50

을

的 证。

5.5

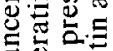

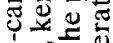

䆑言.

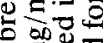

政

으르드.

更

20

政

西

语

늘.

궁용

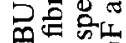

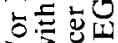

등

空

क

ष)

하을

我过

然造

可

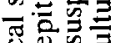

记

은

b.

항하

光政

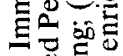

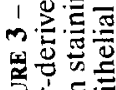

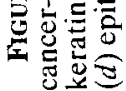


tumor 1

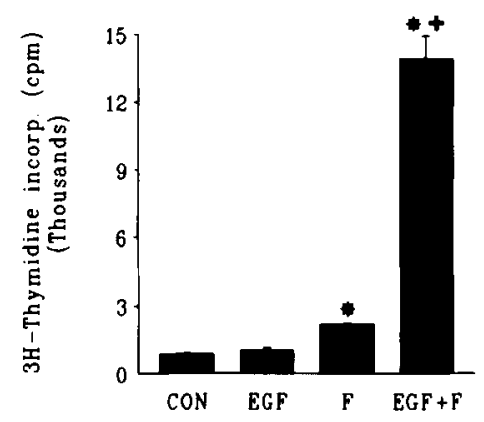

tumor 4

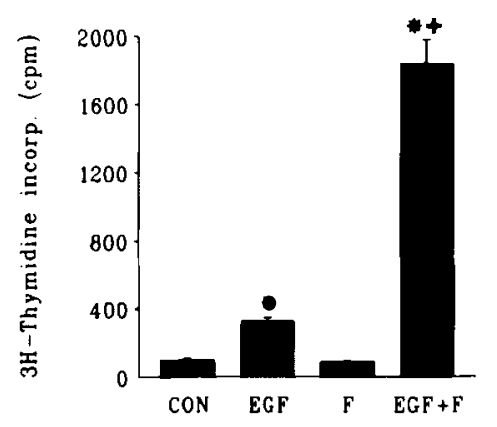

tumor 2

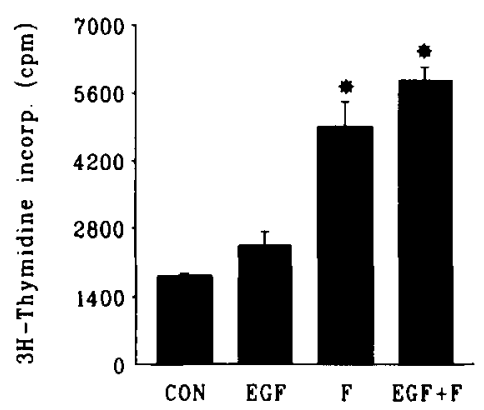

tumor 5

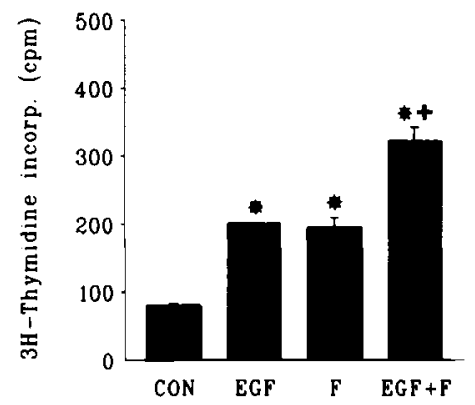

tumor 3

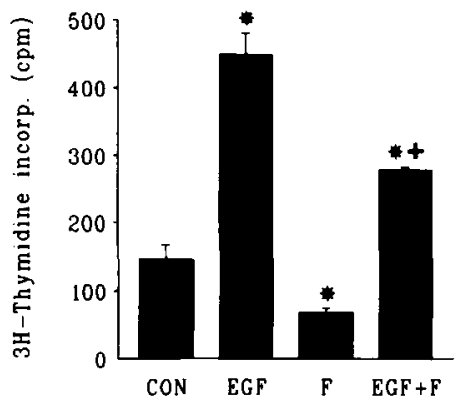

tumor 6

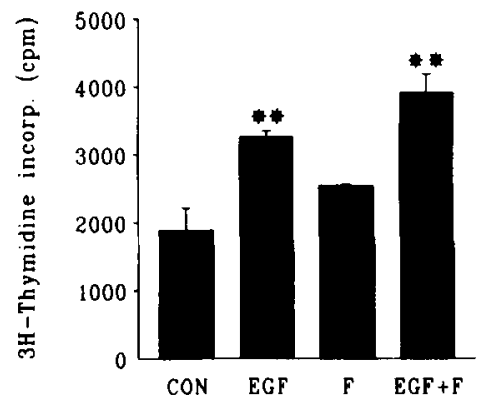

Figure 4 -Effects of breast-cancer-derived fibroblasts $(\mathrm{F})$ and $10 \mathrm{ng} / \mathrm{ml}$ epidermal growth factor (EGF) on ${ }^{3} \mathrm{H}$-thymidine incorporation by Percoll-enriched epithelial cells derived from the same tumors. Fibroblasts and epithelial cells were co-cultured using Transwell tissue-culture inserts as described in the text. ${ }^{*} p<0.01$ and ${ }^{* *} p<0.05 v s$. control; ${ }^{+} p<0.01 v s$. EGF alone. CON $=$ control, $\mathrm{EGF}=10 \mathrm{ng} / \mathrm{ml} \mathrm{EGF}, \mathrm{F}=$ fibroblasts.

from breast-cancer-derived stromal cells capable of stimulating human breast-cancer cell-line proliferation (Enami et al., 1983; Adams et al., 1988; van Roozendaal et al., 1992). In the present study we provide preliminary evidence of the existence of such an autocrine growth-stimulatory mechanism in a co-culture system of primary human breast-cancer cells and stromal cells derived from the same tumors, although the tumors varied considerably. In $50 \%$ of the human tumor-cell cultures we found that tumor-derived stromal cells stimulated the proliferation of epithelial cells derived from the same tumor. In one culture, however, the stromal cells even inhibited epithelial cell proliferation. In 2 tumor-cell cultures we showed that fibroblasts and EGF acted synergistically on epithelial-cell proliferation, while in 3 other cultures the EGF-stimulatory effect was only slightly additive and not synergistic to the fibroblast-stimulated epithelial cell proliferation. Finally, in one culture the tumor-derived fibroblasts even significantly inhibited EGF-stimulated epithelial-cell proliferation. In 2 cultures from "non-malignant" breast-tissue-derived fibroblasts and epithelial cells we also observed an inhibitory effect of fibroblasts on epithelial-cell proliferation. These data are partly in agreement with the results of a recent study by van Roozendaal et al. (1992), who suggested a higher stimulatory response of breast-cancer cell lines to conditioned media of breast-cancer-derived fibroblasts as compared to that of normal breast-tissue-derived fibroblasts. They suggested that this was most likely determined by the phenotypic characteristics of the fibroblast cells involved, which may differ between normal tissue and tumor-derived fibroblasts. Moreover, Adams et al. (1988) also found that normal-tissue-derived fibroblast-conditioned medium had an inhibitory effect on MCF-7 cell proliferation, while conditioned medium from tumorderived fibroblasts was strongly stimulatory. Other investigators have shown either stimulatory (Enami et al., 1983; Horgan et al., 1987; Miller and McInerney, 1988; van Roozendaal et al., 1992) or inhibitory (McGrath, 1983) effects of normal-tissuederived fibroblasts on epithelial cell proliferation. In the same co-culture system which we used in the human primary tumor-cell cultures, we found that normal human-foreskin fibroblasts were only stimulatory on human MCF-7 cell proliferation. It appears very important, therefore, to study stromalepithelial interactions on cells derived from the same tissue specimen.

Interestingly, we found that the tumor-epithelial cells also had a stimulatory effect on fibroblast proliferation. This suggests that, within human breast cancer, an autocrine growthregulatory route exists in which fibroblasts stimulate epithelial cells and epithelial cells stimulate fibroblasts. Breast-cancer cells have been shown to secrete many growth factors (i.e. TGF- $\alpha$, TGF- $\beta$ and PDGF), while fibroblasts are also capable of secreting growth factors (Osborne and Arteaga, 1990), particularly IGFs (van der Burg et al., 1990). In the present study we did not investigate the nature of the epithelial-cell and fibroblast-derived factors responsible for the observed autocrine growth stimulation. However, our results indicate that fibroblasts and growth factors (i.e. insulin, EGF and E2) act additively or synergistically upon the proliferation of malignant breast-cancer cells. In addition, in the human primary-cell cultures we found that fibroblasts have a stimulatory effect on breast-cancer cells, even when both cell types are grown in the presence of EGF and serum. This suggests that 

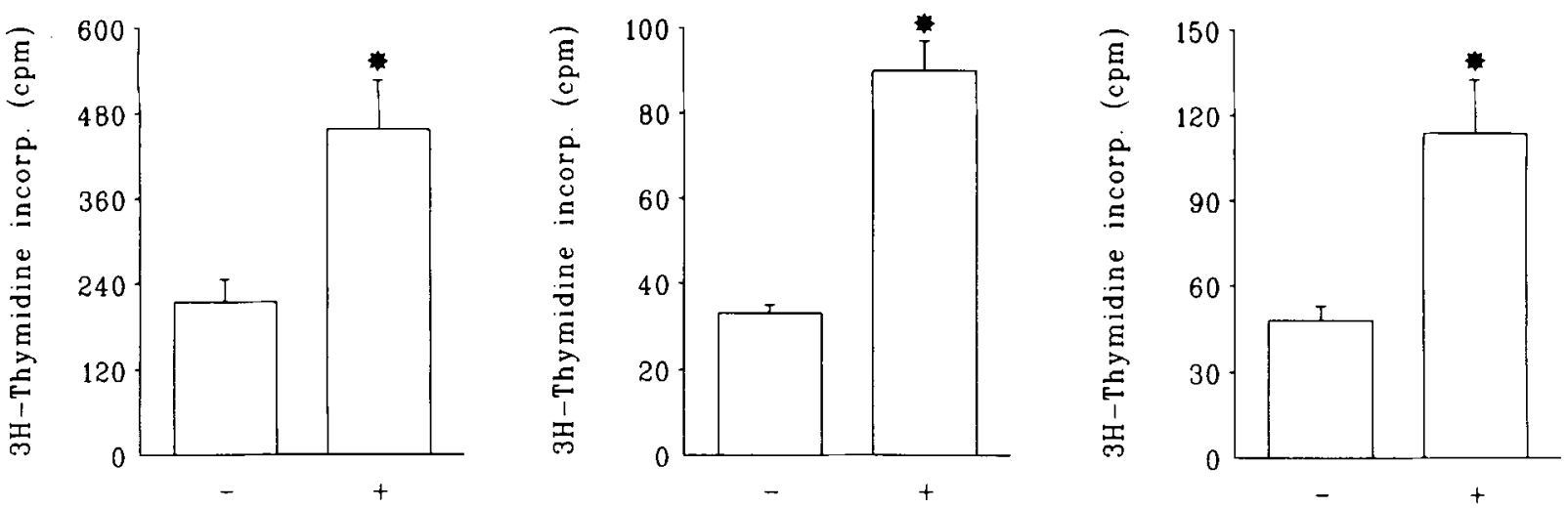

Figure 5 - Effect of Percoll-enriched epithelial breast cancer cells on the growth of fibroblasts derived from the same tumors. Both cell types were co-cultured using Transwell tissue-culture inserts as described in the text. - , without epithelial cells; + , with epithelial cells; * $p<0.01$ vs. fibroblasts without epithelial cells.

TABLE II - EFFECTS OF EGF AND SOMATOSTATIN ANALOGUE OCTREOTIDE ON ${ }^{3} \mathrm{H}$-THYMIDINE INCORPORATION BY FIBROBLASTS CO-CULTURED WITH PRIMARY BREAST-CANCER CELLS

\begin{tabular}{cccc}
\hline \multirow{2}{*}{$\begin{array}{c}\text { Tumor } \\
\text { number }\end{array}$} & \multicolumn{3}{c}{${ }^{3}$ H-thymidine incorporation (cpm per dish) } \\
\cline { 2 - 4 } & Control & EGF $(10 \mathrm{ng} / \mathrm{ml})$ & Octreotide $(1 \mathrm{nM})$ \\
\hline 1 & $428 \pm 110$ & $1450 \pm 153^{1}(339)$ & $685 \pm 279$ \\
2 & $457 \pm 70$ & $1417 \pm 6^{1}(310)$ & $349 \pm 23$ \\
3 & $29 \pm 2$ & $58 \pm 5^{1}(200)$ & $33 \pm 3$ \\
4 & $77 \pm 11$ & $177 \pm 7^{1}(230)$ & $56 \pm 5$ \\
5 & $90 \pm 7$ & $126 \pm 6^{1}(140)$ & $58 \pm 1^{1}(64)$ \\
6 & $114 \pm 19$ & $235 \pm 20^{1}(206)$ & $138 \pm 31$ \\
\hline
\end{tabular}

${ }^{1} p<0.01 v s$. control; values are mean $\pm \mathrm{SE}$, control $=$ fibroblasts co-cultured with primary breast-cancer cells. Numbers in parentheses represent the percentage of treatment $v s$. control values.

(unique) factors, other than the above growth-promoting compounds, are responsible for the growth-promoting effects induced by fibroblasts. The observed opposite effects of "non-malignant breast tissue"- and "breast-tumor tissue"derived fibroblasts on epithelial cell proliferation suggest that the ratios of growth-stimulatory and growth-inhibitory factors secreted may differ between "normal" and "tumor" fibroblasts, since it is unlikely that fibroblasts produce one specific growth factor only.

In approximately $50 \%$ of human breast-cancer specimens, receptors for somatostatin have been demonstrated, while EGF-receptors were found in $25 \%$ of the samples containing somatostatin receptors. However, in only $8 \%$ of these cases were the 2 receptor types topographically overlapping (Reubi et al., 1990). On the basis of these data Reubi et al. (1990) suggested that, in the majority of breast tumors, it is unlikely that tumor biology is influenced by a direct interaction of somatostatin and EGF through specific receptors in a particular cell. In a wide variety of experimental tumor models, including breast cancer, growth-inhibitory effects of longacting somatostatin analogues have been demonstrated in vivo and in vitro (Schally, 1988; Lamberts et al., 1991). The in vivo tumor-growth-inhibitory effects of somatostatin analogues may act indirectly via the inhibition of angiogenesis, immune modulatory effects and inhibition of the secretion of "endocrine" growth factors such as growth hormone, prolactin and IGF-I, as well as via direct effects on tumor cells via specific somatostatin receptors. These last-named effects include inhibition of EGF-receptor activity via the stimulation of a tyrosine phosphatase or inhibition of the secretion of autocrine and paracrine growth factors (Lamberts et al., 1991). Because our study showed clear evidence of the existence of a paracrine growth-regulatory mechanism, we also studied the effect of the somatostatin analogue octreotide on epithelial-cell and fibroblast proliferation with or without co-culture. We found that octreotide had no effect on basal and fibroblast-stimulated epithelial cell proliferation in 5 of 6 tumors, while in one tumor octreotide inhibited epithelial-cell proliferation in the absence of fibroblasts only. Surprisingly, we found in one culture that octreotide significantly inhibited the proliferation of fibroblasts co-cultured with epithelial cells. Although we did not investigate the somatostatin-receptor status of the tumors, it can be speculated that octreotide inhibits the secretion of growth factors by the epithelial tumor cells, thereby indirectly inhibiting growth of the co-cultured fibroblasts. In the 7-day co-culture period used in our study, this growth-inhibitory effect of octreotide upon fibroblast proliferation did not result in an indirect growth inhibition of epithelial cells. Therefore, more studies are clearly needed to evaluate the potential role of the somatostatin analogue octreotide in the treatment of breast cancer.

In conclusion, our study emphasizes the need to investigate the role of stromal cells in breast-cancer epithelial-cell proliferation, as well as their role in interfering with drug-induced manipulation of breast-cancer cell growth.

\section{ACKNOWLEDGEMENTS}

This work was supported by a project grant (NKB-91-12) from the Dutch Cancer Society.

\section{REFERENCES}

Adams, E.F., Newton, C.J., Braunsberg, H., Shaikh, N., Ghilchik, M. and JAMES, V.H.T., Effects of human breast fibroblasts on growth and 17-beta-estradiol dehydrogenase activity of MCF-7 cells in culture. Breast Cancer Res. Treat., 11, 165-172 (1988).
BAND, V. and SAGER, R., Distinctive traits of normal and tumorderived human mammary epithelial cells in a medium that supports long-term growth of both cell types. Proc. nat. Acad. Sci. (Wash.), 86, 1249-1253 (1989). 
EnAmI, J., EnAmI, S. and Koga, M., Growth of normal and neoplastic mouse mammary epithelial cells in primary culture: stimulation by conditioned medium from mouse mammary fibroblasts. Jap. J. Cancer Res, 74, 845-853 (1983).

HASLAM, S.Z., Mammary fibroblast influence on normal mouse mammary epithelial cell responses to estrogen in vitro. Cancer Res., 46, 310-316 (1986)

Hofland, L.J., van Koetsveld, P.M. and Lamberts, S.W.J., Percoll density gradient centrifugation of rat pituitary tumor cells: a study of functional heterogeneity within and between tumors with respect to growth rates, prolactin production and responsiveness to the somatostatin analog SMS 201-995. Europ. J. Cancer, 26, 37-44 (1990).

Horgan, K., JoneS, D.L. and MANSEl, R.E., Mitogenicity of human fibroblasts in vivo for human breast cancer cells. Brit. J. Surg., 74, 227-229 (1987)

Horgan, K., Jones, D.L. and Mansel, R.E., Stromal stimulation of human breast cancer growth and development. In: F. Bresciani, R.J.B. King, M.E. Lippman and J-P. Raynaud (eds.), Progress in cancer research and therapy, pp. 179-182, Raven Press, New York (1988)

LAMBerTS, S.W.J., Krenning, E.P. and ReubI, J.-C., The role of somatostatin and its analogs in the diagnosis and treatment of tumors. Endocr. Rev., 12, 450-482 (1991).

Lippman, M.E., Dickson, R.B., Bates, R.B., Knabbe, C., Huff, K., Swain, S., McManaway, M., Bronzert, D., Kasid. A. and Gelmann, E.P., Autocrine and paracrine growth regulation of human breast cancer. Breast Cancer Res. Treat, 7, 59-70 (1986).

MCGrath, C.M., Augmentation of response of normal mammary epithelial cells to estradiol by mammary stroma. Cancer Res., 43, 1355-1360 (1983).

MILleR, F.R. and MCINERNEY, D., Epithelial component of hosttumor interactions in the orthotopic site preference of a mouse mammary tumor. Cancer Res., 48, 3698-3701 (1988).

Osborne, C.K. and ARTEAGa, C.L., Autocrine and paracrine growth regulation of breast cancer: clinical implications. Breast Cancer Res. Treat., 15, 3-11 (1990).
Reubi, J.C., Waser, B., Foekens, J.A., Klun, J.G.M., Lamberts, S.W.J. and LAISSUE, J., Somatostatin receptor incidence and distribution in breast cancer using receptor autoradiography: relationship to EGF receptors. Int. J. Cancer, 46, 416-420 (1990).

Rosen, N., Yee, D., Lippman, M.E., Paik, S. and Cullen, K.J., Insulin-like growth factors in human breast cancer. A review. Breast Cancer Res. Treat., 18, \$55 (1991).

SCHALly, A.V., Oncological applications of somatostatin analogues. Cancer Res., 48, 6977-6985 (1988).

SMiTH, H.A., The biology of human mammary epithelium in culture: the path from viral transformation to human cancer. In: J. Campisi, D.D. Cunningham, M. Inouye and M. Riley (eds.), Perspectives on cellular regulation: from bacteria to cancer, pp. 225-234, Wiley-Liss, New York (1991).

SNEdeCOR, G.W. and CoCHRAN, W.G., Statistical methods, 7th ed., pp. 235-237, Iowa State University Press, Ames (1980).

Sykes, J.A., Whitescarver, J., Briggs, L. and Anson, J.H., Separation of tumor cells from fibroblasts with use of discontinuous density gradients. J. nat. Cancer Inst., 44, 855-864 (1970).

VAN DER Burg, B., Isbrücker, L., VAN SElm-MiltenburG. A.J.P., DE LAAT, S.W. and VAN ZOELEN, E.J.J., Role of estrogen-induced insulin-like growth factors in the proliferation of human breast cancer cells. Cancer Res., 50, 7770-7774 (1990).

Van der Burg, B., Rutteman, G.R., Blankenstein, M.A., de LAat, S.W. and VAN ZOELEN, E.J.J., Mitogenic stimulation of human breast cancer cells in a growth factor-defined medium: synergistic action of insulin and estrogen. J. cell. Physiol., 134, 101-108 (1988).

van Roozendaal, C.E.P., van Ooljen, B., Klijn, J.G.M., ClaAssen, C. EgGermont, A.M.M., HenZen-Logmans, S.C. and Foekens, J.A. Stromal influences on breast cancer cell growth. Brit. J. Cancer, 65, 77-81 (1992).

Vennin, P., Peyrat, J.P., Bonneterre, J., Louchez, M.M., Harris, A.G. and DEMAILLE, A.. Effect of the long-acting somatostatin analog SMS 201-995 (Sandostatin) in advanced breast cancer. Anti-Cancer Res., 9, 153-156 (1989). 